\title{
The relationship between country and individual household wealth and climate change concern: The mediating role of control
}

\author{
Kelly Fielding, University of Queensland (Australia) \\ Céline Nauges, Toulouse School of Economics (France) \\ Sarah Wheeler, University of Adelaide (Australia)
}

\begin{abstract}
Although past findings are inconclusive, there is evidence of a negative relationship between wealth — at the household and country level—and climate change concern. One explanation for this relationship is that wealth provides a buffer against the risks of climate change, leading people in wealthy countries or wealthy households to perceive a greater sense of control over climate change impacts which in turn results in lower levels of concern. We tested this hypothesis with data sourced from the OECD Environment Directorate which conducted a detailed household survey in 2011 of 11 OECD countries $(\mathrm{N}=10,162)$. Our results accord with past studies showing a significant negative relationship between country and household wealth and individuals' perceptions of the seriousness of climate change. Moreover, our findings suggest that this relationship is mediated through sense of control, measured at the country level by the readiness index and at the household level by the extent of adoption of energy efficiency improvements. These findings raise the question of how best to incentivise action on climate change amongst those with the ability - but not necessarily the motivation - to respond.
\end{abstract}

Key Words: climate change concern; wealth; control; country wealth; household wealth.

Acknowledgment: Céline Nauges acknowledges funding from the French National Research Agency (ANR) under the Investments for the Future (Investissements d'Avenir) program, grant ANR-17-EURE-0010. 


\section{Introduction}

In November 2017 more than 15,000 scientists from around the world sent a 'letter to humanity' warning of a range of catastrophic environmental calamities, including global climate change, that imperil the earth's biosphere (Ripple et al. 2017). This second notice, the first was signed in 1992 by 1,700 scientists, highlights the mismatch between scientists and citizens' level of concern about environmental issues, particularly climate change. Although polling from around the world shows substantial numbers of people who are concerned about climate change, there are also significant minorities who are relatively less concerned, for example, in the US (Leiserowitz et al. 2017); Australia (Lowy Institute 2019); Canada (The Environics Institute 2014); and some European countries (European Commission 2017).

The extent to which citizens are concerned about climate change is important because levels of concern can encourage or stymy individual action and undermine the political will to implement climate change policy. Models of environmental decision-making point to beliefs and concern as critical antecedents to people taking action to address environmental problems. For example, the value-belief-norm model (Stern 2000) theorizes that awareness of consequences influences a person's sense of responsibility and in turn their sense of personal obligation to act on behalf of the environment.

If we accept that citizens' concern about climate change is an important precursor for climate change action, then the question of what predicts climate change concern becomes a critically important one. Past research has pointed to a wide variety of characteristics (including cognitive, experiential, socio-cultural and demographic) that predict individuals' beliefs and the way they perceive the risk of climate change (Hornsey et al. 2016; van der Linden 2017). Recently, researchers have also acknowledged that the material circumstances of individuals and countries may also relate to climate change belief (Sandvik 2008; Lo 
2016). This focus aligns with the climate change rhetoric that it is those nations and individuals that have the least ability to cope that will be most vulnerable to climate change impacts, whereas wealthier nations and people will have the resources to adapt (cf. Kelly and Adger 2000). This rhetoric foregrounds wealth as an important influence in how concerned individuals and nations may be about climate change. In the current research we use a unique and highly detailed OECD (Organisation for Economic Co-operation and Development) household survey database across 11 countries to focus on the relationship between wealthof individuals and nations - and the perceived seriousness of climate change. Further, we explore whether a sense of control can help to explain the relationship between wealth and climate change perceptions.

\section{Household income, national wealth and climate change attitude literature}

Past research has shown mixed findings for the relationship between household income and environmental concern. On the one hand, Franzen and Vogl have demonstrated across 33 nations that respondents in higher income households are more concerned about the environment (Franzen and Vogl 2013a; 2013b). On the other hand, Lo (2016) found that higher household income was related to less perceived environmental risk and Milfont et al. (2014) found no significant relationship between household income and climate change beliefs.

Research has also investigated the wealth-environmental concern relationship at the country level drawing on data from large multi-country surveys. Some studies have revealed a positive relationship: Franzen and Vogl (2013a) found that individuals in countries with higher Gross Domestic Product (GDP) reported greater environmental concern and Lo and Chow (2015) found that GDP was significantly and positively associated with the importance of climate change relative to other environmental issues. Other high quality studies have 
shown a negative relationship such that individuals in higher GDP countries judge climate change as less serious (Kvaløy, Finseraas and Listhaug 2012; Mostafa 2016; Sandvik 2008) and rising temperatures related to climate change as less dangerous (Lo and Chow 2015). Milfont et al. (2014) also found that individuals in regions that were more socio-economically deprived had greater belief in climate change whereas Kim and Wolinsky-Nahmias (2014) did not find a relationship between GDP and individuals' strength of climate change concern.

Inglehart's $(1977 ; 1990)$ theory of post-materialism has been the main theoretical framework used to understand the relationship between wealth and environmental concern. According to this perspective, increasing affluence allows people to shift their focus from meeting basic needs, to valuing and caring for higher-order issues such as the environment. Hence, as people and countries attain greater wealth, citizens' concern for the health of the environment increases. This perspective has been questioned as studies have shown evidence that runs counter to the theory (e.g., Dunlap and Mertig 1995; Dunlap and York 2008).

Lo and Chow (2015) advance a distinction that could help to reconcile the contradictory findings: they highlight that climate change concern has two distinct components - one that relates to the importance of climate change and one that relates to risk perceptions. In support of this contention they show that national wealth (GDP) correlates positively with measures of climate change importance but negatively with climate change risk perceptions. Lo (2016) argues that wealth and income determine the level of risk people are willing to take. He contends that those who have less economic resources are less willing to take risks. In a similar vein, Slovic $(1987 ; 2000)$ proposes that individuals' risk perceptions are affected by the ability individuals have to control those risks. He argues that the ability to manage and respond to adverse events is tightly linked to individuals' financial resources; hence wealthier individuals can more easily ensure against all sorts of risks, recover from 
material damage, or find a place to relocate in case of a forced displacement. ${ }^{1}$ Higher income and resources could therefore lead to an increased sense of control about the world and future outcomes, reduced sense of personal vulnerability and therefore reduced concern about climate change issues.

The sense of control that individuals may accrue from private wealth may also manifest at the country level. Wealthier countries are usually better equipped to manage or avoid adverse consequences of climate change. For example, wealthier countries usually have: well-functioning insurance markets; large defence and emergency personnel to cope with natural disasters; options to relocate for those who have to be displaced; increased infrastructure expenditure to 'flood-proof' areas; and adequate social security systems and relief packages to those affected by a catastrophic event (cyclone, floods etc.) etc. (Lo 2016; Sandvik 2008). Hence, individuals' level of climate change concern might be driven not only by their own ability and resources to cope with the risk of catastrophic events but also by the level of collective protection their country is capable of achieving.

This theoretical reasoning provides an explanation for why a negative relationship might emerge between wealth and climate change concern. It suggests that wealthy individuals living in affluent countries are less concerned about climate change because wealth increases their sense of control through having the resources to protect themselves against the risks of climate change. In other words, sense of control mediates the relationship between wealth and climate change concern. Although this proposition makes theoretical sense, to our knowledge it has not been tested in previous research.

In this article we use household data from 11 countries and test the relationship between household income and country wealth and individuals' concern about climate

\footnotetext{
${ }^{1}$ For example, those households who can afford to build a floating house (i.e. a house that rises with the water levels) are likely to feel less concerned about future risks of flooding.
} 
change. Consistent with the notion that wealth may buffer against perceived risk of climate change — through increasing individuals' sense of control—we hypothesise:

H1: Households and countries with higher wealth will have less concern for climate change.

H2: The relationship between household and country wealth and their climate change concerns will be mediated by sense of control.

An important contribution of the current study is to further understand the wealth and climate change concern relationship through testing sense of control as a potential mediator of the relationship. As we noted previously, although researchers have theorized that wealth reinforces the feeling of 'being in control' in case of potential adverse effects of climate change, to our knowledge there has been no empirical test of control—or variables that can act as proxies of this construct - as a mediator. The following sections describe our attempt to measure control and its relationship with climate change concerns in 11 OECD countries.

\section{Data, variables, and methods for mediation analysis}

\subsection{Data}

Data is sourced from the OECD Environment Directorate which conducted a detailed household survey in 2011 on Environmental Policy and Individual Behaviour Change in 11 OECD countries: Australia, Canada, Chile, France, Israel, Japan, Korea, the Netherlands, Spain, Sweden and Switzerland; with each online survey sample stratified for age, gender, income and region. Around 1,000 households were surveyed in each country on their opinions, attitudes and behaviour related to a number of environmental fields. Delegates from participating countries and a variety of survey experts designed the survey for each country, with translations provided for each country. A pilot survey was conducted on 500 people, and 
rigorous stratification and sampling procedures were followed to ensure representativeness (for further details, see OECD 2014).

\subsection{Variables}

\subsubsection{Dependent and mediating variables}

The dependent variable in this study is respondents' climate change concern, which was measured on a scale from zero (climate change was regarded as not serious at all) to 10 (climate change was regarded as extremely serious), so that a higher value indicates greater concern. We construe seriousness of climate change as more likely to reflect the risk component of environmental concern (cf. Lo and Chow 2015). Wealth at the country level was measured as Gross National Income (GNI-per capita in 2011, in thousand USD, sourced from World Bank). The measure of wealth at the household level was collected from the OECD survey and was household annual after tax income in thousand USD.

Two variables served as proxies for sense of control, our proposed mediator. At the country level we used the readiness score produced by the University of Notre Dame (US) through their Global Action Initiative (for further details on ND-GAIN, see http://gain.org). As described on the ND-GAIN website, the readiness score measures a country's ability to leverage investments and convert them to adaptation actions. ND-GAIN measures overall readiness by considering three components-economic readiness, governance readiness and social readiness. Economic readiness captures the ability of a country's business environment to accept investment that could be applied to adaptation that reduces vulnerability (reduces sensitivity and improves adaptive capacity). Governance readiness captures the institutional factors that enhance application of investment for adaptation. Social readiness captures factors such as social inequality, information and communication technology infrastructure, education, and innovation that enhance the mobility of investment and promote adaptation 
actions. The readiness score is measured on a $0-1$ scale with higher scores on the index reflecting greater capacity of the country to attract and mobilize economic resources to cope

following set of energy-efficient appliances was considered as a form of control in this study:

low-energy light bulbs; energy-efficient windows; thermal insulation of walls/roof; heat scores calculated over the number of non-missing responses; ${ }^{3}$ and is standardised to be

between 0-100. A higher score on the index indicates greater household energy-efficiency adoption which we use as a proxy for greater sense of control over potential adverse climate or temperature extremes that could arise from climate change) that might impact on their lives. Having a greater number of energy efficient and sustainable appliances in the home may

\footnotetext{
${ }^{2}$ Respondents have not been asked in the survey what the main reason for adopting energy-efficient devices was but there is some evidence that cost savings are not the primary driver of adoption. When respondents were asked to state the importance of seven factors (using a scale varying from 0 to 10) that would encourage energy conservation, the factor which came out as the least important (on average) was: "higher energy prices", while the factor that was considered the most important was: "less expensive to invest in energy-efficient equipment". So the investment cost of the equipment is considered too high for some households but reducing the energy bill does not appear as the main reason why they would invest (if they were not budget-constrained). In what follows we assume that feeling better protected at home against the adverse effects of climate change such as higher temperature and/or longer drought spells is one of the main factors driving the adoption of energy-efficient equipment.

${ }^{3}$ The score is set to missing if installation of the equipment was not possible (e.g. because the household was renting and only the landlord could install the equipment).
} 
give people the sense that they are prepared for future environmental challenges and give them sense of being in control.

\subsubsection{Independent variables}

Other independent variables that were used in our regression models were based on findings from the climate change literature (e.g. van der Linden 2017) and available information from the OECD survey. The full set of variables used in the regression models are described in Table A1 and summary statistics are shown in Table A2, both in Appendix A. We consider the following independent variables:

Respondent's and household's socio-demographic characteristics: Respondent's gender, age, and education; household's children (a dummy variable indicating the presence in the household of at least one member who is below 18 years of age), household annual after tax income; place of living (urban or rural area) (Hornsey et al. 2016 meta-analysis indicates the importance of all these variables), and a dummy variable indicating whether the household's energy bill is based on its actual level of energy use (to test whether economic incentives on energy use can influence climate change concerns, as suggested by the economic literature; e.g. Ohler and Billger 2014).

Respondents' attitudes and opinions in different domains were measured including: trust in information coming from researchers, scientists, and experts (e.g. Hmielowski et al. 2014 showed increased trust in scientists is associated with climate change beliefs); appraisal of the seriousness of personal safety issues (concern over climate change may be influenced by broader social, political and economic concerns that are related to it, such as the failure of the government to protect the public interest; Lo 2016); support of, or participation in, activities of charitable organisations (see, e.g., Knez 2013 on the links between values such as 
egoism and altruism, and concern for climate change); respondent's average level of satisfaction towards the quality of his/her local environment (previous work has found a negative relationship between quality of local environment and willingness to pay for environmental issues [Millock and Nauges 2014]); and agreement/disagreement with the following two statements: "Environmental issues should be dealt with primarily by future generations" and "Environmental issues will be resolved primarily through technological progress". Previous research has indicated the importance of environmental attitudes, as well as the importance of political ideology (e.g. Hornsey et al 2016; Lo 2016; Nauges and Wheeler 2017; van der Linden 2017). Answers to the two environmental statements were used as proxy for political ideology (with agreement indicating proximity to conservative ideology as found in a cross-national study for developed countries by Nawrotzki 2012, see Appendix A). ${ }^{4}$ the Environmental Performance Index (EPI) which ranks how well countries perform in two broad policy areas: protection of human health and protection of ecosystems; the average percentage of the country population that was affected by natural disasters classified as either droughts, floods, or extreme temperature events in 2009; the number of floods recorded from 1985-2011; the mean temperature over the years 2006-2010 (five years prior to the survey); the ratio of mean temperature over 2006-2010 to mean temperature over 1911-2010; and the main orientation of the political party ruling the country in 2011 (van der Linden 2017 provides overview of the literature results to date of these country-specific influences on climate change beliefs).

\footnotetext{
${ }^{4}$ Unfortunately our dataset does not include information on race or political ideology. These characteristics could be important omitted variables since there is consistent evidence that older white men, living in rural areas, identify as a Christian, and who hold conservative political views care less about climate change issues (Lee et al. 2015; Hornsey et al. 2016; van der Linden 2017).
} 


\subsection{Mediation analysis}

As previously discussed, we hypothesize that the relationship between wealth (household and country) and climate change concern is mediated by a sense of control. This mediation was assessed by whether: i) the readiness score plays the role of a mediator in the relationship between GNI per capita and climate change concern; and ii) the adoption of costly energyefficient equipment plays the role of a mediator in the relationship between households' income and climate change concern. To test mediation we follow the recommendations of Baron and Kenny (1986). Although this approach has its limitations, it is one of the most widely used methods to assess mediation in basic regression models, usually involving only a dependent variable $(\mathrm{Y})$, an independent variable $(\mathrm{X})$, and the hypothesized mediator $(\mathrm{M})$. The four steps involve running regression models between the: i) dependent variable $(\mathrm{Y})$ and the independent variable $(\mathrm{X})$; ii) independent variable $(\mathrm{X})$ and the hypothesized mediating variable $(\mathrm{M})$; and iii) dependent variable $(\mathrm{Y})$ and both the independent $(\mathrm{X})$ and the mediating (M) variables. The role of $\mathrm{M}$ as a mediating variable is assessed through tests of significance of the parameters in the three above regressions. ${ }^{5}$

We follow Baron and Kenny (1986)'s approach to test whether the readiness score is a mediator for GNI per capita by estimating two regression models: the first one (Model 1) includes GNI per capita as an independent variable along with the full set of explanatory variables (combining household- and country-level variables), but excludes the readiness

\footnotetext{
${ }^{5}$ The identification of a pure mediating effect requires strong assumptions which are likely not to be satisfied apart from very specific settings where $X$ features a randomized intervention. These assumptions include: the exogeneity of X; no reverse causality (i.e., Y should not cause X); no omitted variable; X and M do not interact to cause X; and usual assumptions on the error term. The identification of mediating effects becomes even more difficult when the model involves multiple independent variables, as is the case in our study. In such cases it is difficult to know with certainty whether the hypothesized mediating variable is a "real" mediator, a covariate, a moderator, or a confounding variable (MacKinnon, Fairchild and Fritz 2007). M would be called a confounding variable if: $\mathrm{M}$ causes both $\mathrm{X}$ and $\mathrm{Y}$ and ignoring $\mathrm{M}$ leads to incorrect inference about the relationship between $\mathrm{X}$ and $\mathrm{Y}$. $\mathrm{M}$ would be called a covariate if: $\mathrm{M}$ improves the prediction of $\mathrm{Y}$ by $\mathrm{X}$ but does not substantially alter the relation of $\mathrm{X}$ to $\mathrm{Y}$ when $\mathrm{Z}$ is included. Finally $\mathrm{M}$ would be called a moderator if the relationship between $\mathrm{X}$ and $\mathrm{Y}$ differs at different values of $\mathrm{M}$.
} 
score. The second model (Model 2) is the same as Model 1 but includes the readiness score as an additional independent variable. For the readiness score to be a mediator, we need the following two conditions to be verified: i) the coefficient of GNI per capita is statistically significant in Model 1 but loses significance in Model 2; and ii) the coefficient of the readiness score is negative and statistically significant in Model 2.

Models 1 and 2 were specified as mixed multi-level regression models in order to account for the fact that the models feature independent variables measured at two different levels: the household or individual, and the country. Mixed multi-level regression models enable the inclusion of both fixed and random parameters. Fixed parameters assume that the impact of the variable is the same across all countries while random parameters allow for the impact of the variable to vary from one country to another. The two models were estimated by Maximum Likelihood using the 10,162 household-level observations available. A number of specifications were tested (with different sets of fixed and random parameters), with tables in the next section presenting the models that provided the best fit.

We could not follow the exact same strategy to test whether the index measuring the adoption of energy-efficient equipment is a mediator for households' income due to the presence of reverse causality (Nauges and Wheeler 2017). Using the same data these authors showed that households' climate change concern was a determinant of adoption of energyefficient equipment, hence leading to a reverse causality problem in models featuring households' climate change concern as the dependent variable and adoption index as an independent variable. Reverse causality creates estimation biases and hence produces misleading estimated coefficients. We argue that the reverse causality operates at the household level (the household is better equipped and may hence feel less concerned about climate change) but that it would be less likely to be observed at a higher level of aggregation such as the region or state. Hence, in order to test if the adoption index is a mediator for 
households' income and to avoid estimation biases due to reverse causality at the household level, we test the mediation model using regional-averages instead of household data. Model 3 (excluding the adoption index, i.e., the hypothesized mediator) and Model 4 (including the adoption index) are estimated using 162 observations corresponding to regional averages of all dependent and independent variables. Models 3 and 4 were specified as linear regression models since mixed multi-level regression models did not prove superior in this case and were estimated by Ordinary Least Squares.

\section{Results}

In what follows we graphically illustrate simple correlations between climate change concern and wealth at the country level (Section 4.1.) and at the regional level (Section 4.2.). We report and discuss the results of the mediation analysis testing mediation at the country level (Models 1 and 2; 10,162 observations) in Section 4.3 and the outcome of the mediation analysis run on the regional-level dataset (Models 3 and 4; 162 observations) in Section 4.4.

\subsection{Overview of the relationship between country climate change concerns and wealth/readiness}

Table 1 statistics show that households living in the Netherlands and Australia, two countries that are relatively wealthy and known to be vulnerable to climate change, expressed the least concern about climate change (average climate change concern score in the Netherlands: 6.60; average score in Australia: 6.88), whereas households living in Korea and Chile, the two countries with the lowest GNI per capita, are the most concerned (average score in Korea: 8.77; average score in Chile: 8.87 ). 


\begin{tabular}{lcccc}
\hline Obs. & $\begin{array}{c}\text { GNI per } \\
\text { capita (USD) }\end{array}$ & $\begin{array}{c}\text { Hh annual } \\
\text { income } \\
\text { (USD) }\end{array}$ & $\begin{array}{c}\text { Mean climate } \\
\text { change concern } \\
(0-10)\end{array}$ \\
\hline Chile & 1,027 & 12,290 & 17,596 & 8.87 \\
Korea & 1,116 & 22,620 & 34,987 & 8.77 \\
Israel & 1,168 & 31,170 & 34,404 & 7.93 \\
Spain & 1,101 & 31,280 & 38,027 & 7.95 \\
France & 1,227 & 44,220 & 49,421 & 7.40 \\
Japan & 1,043 & 45,190 & 62,679 & 7.54 \\
Canada & 1,122 & 46,860 & 54,432 & 7.35 \\
Australia & 996 & 50,060 & 63,076 & 6.88 \\
Netherlands & 1,301 & 53,130 & 50,134 & 6.60 \\
Sweden & 1,012 & 56,010 & 53,848 & 7.21 \\
Switzerland & 1,089 & 79,320 & 80,663 & 7.48 \\
\hline
\end{tabular}

Notes: GNI $=$ Gross national income; $\mathrm{Hh}=$ household

Figures 1-3 below further illustrate the negative relationship between wealth and climate and climate change concern (vertical axis) at the country level: households living in wealthier countries exhibit, on average, a lower level of climate change concern.

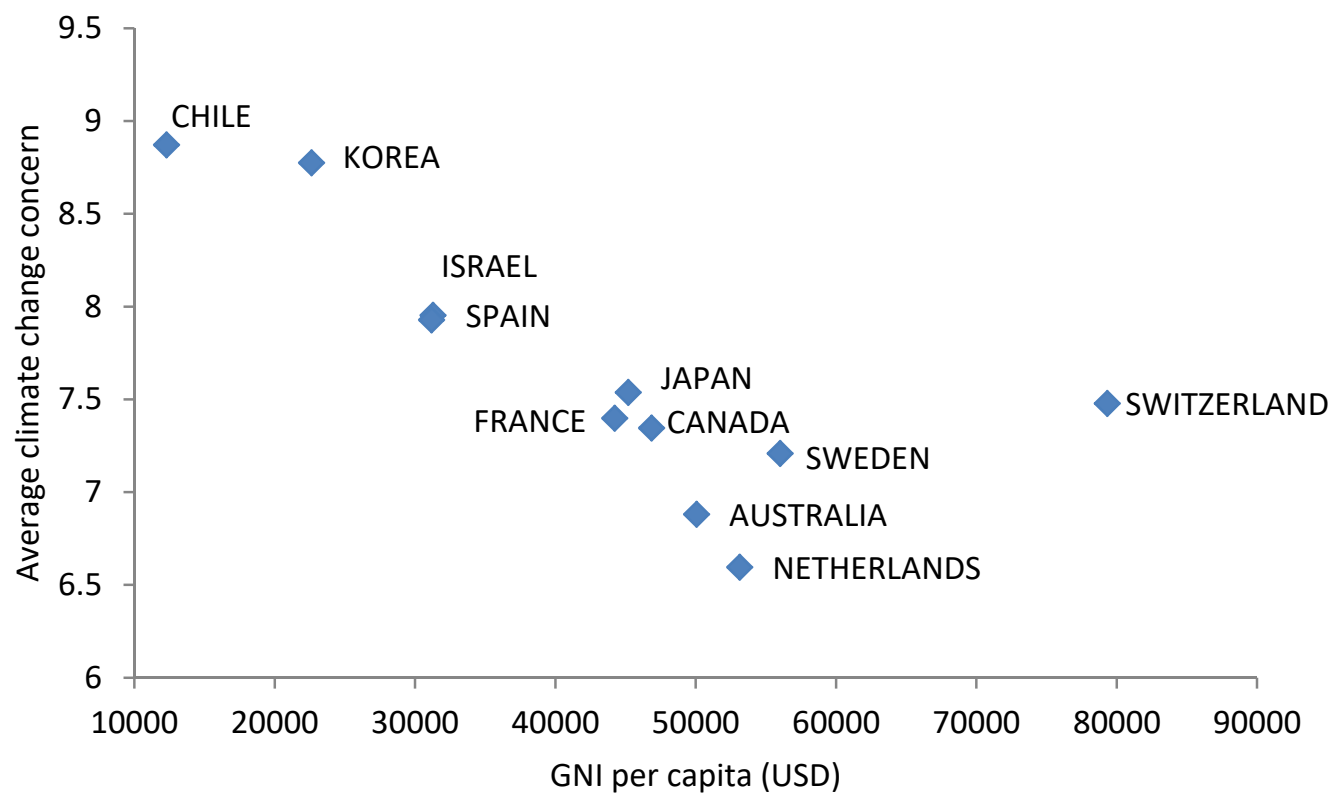


310 Consistent with our hypothesis that greater country wealth will be related to greater control-

311 as measured by the readiness index - there is a positive relationship between a country's GNI

312 per capita (horizontal axis) and its readiness score (vertical axis), which indicates that

313 wealthier countries are more resilient and are better prepared for adaptation to climate change

314 (Figure 2). Countries with higher readiness scores and hence better preparedness and

315 resilience also exhibit lower average concern about climate change in general (Figure 3).

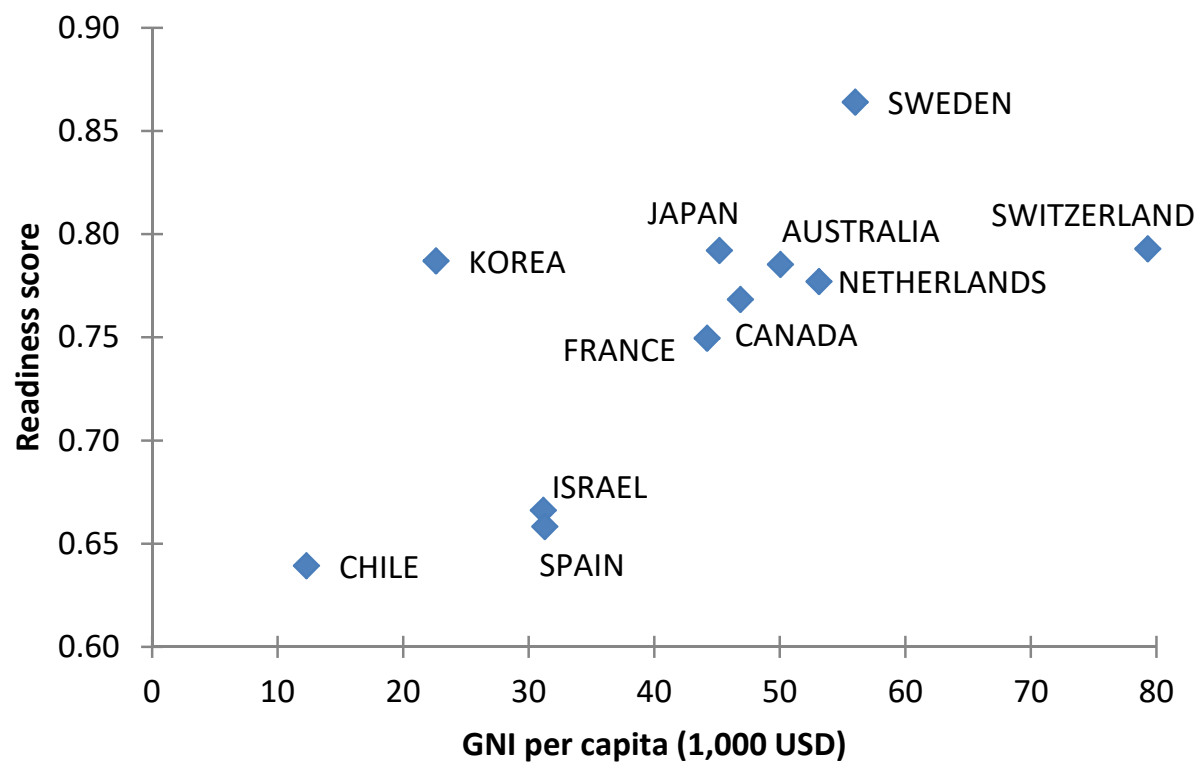




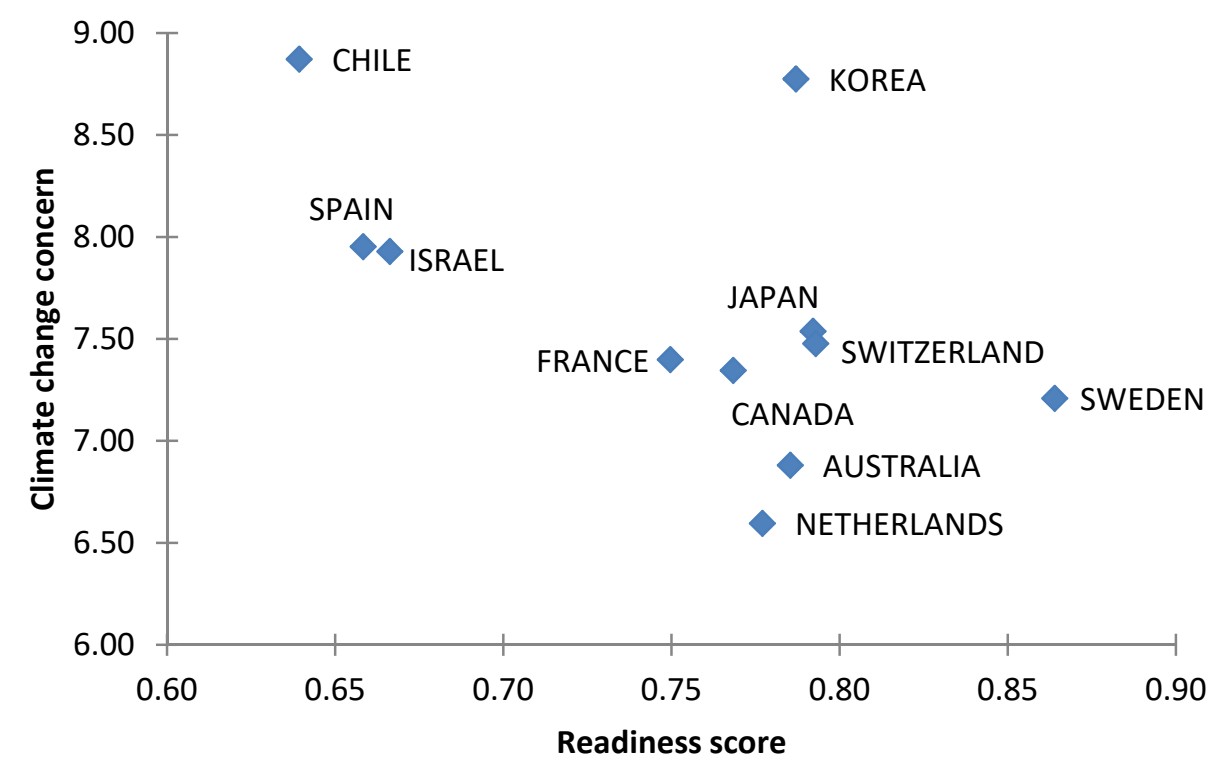
wealth/adaptation

Figures 4 and 5 consider regional averages of household's income and climate change concern computed from households' responses to the survey. Our data cover 162 regions or states in total across the 11 countries. ${ }^{6}$ Similar to the country level, there is a negative

327 relationship between households' wealth (here measured by the average households' annual 328 income in the region) and the average level of concern about climate change (Figure 4).

\footnotetext{
${ }^{6}$ In each country the number of regions/states includes: Australia: 8; Canada: 11; Chile: 15; France: 22; Israel: 6; Japan: 8; Korea: 16; Netherlands: 12; Spain: 17; Sweden: 21; and Switzerland: 26.
} 


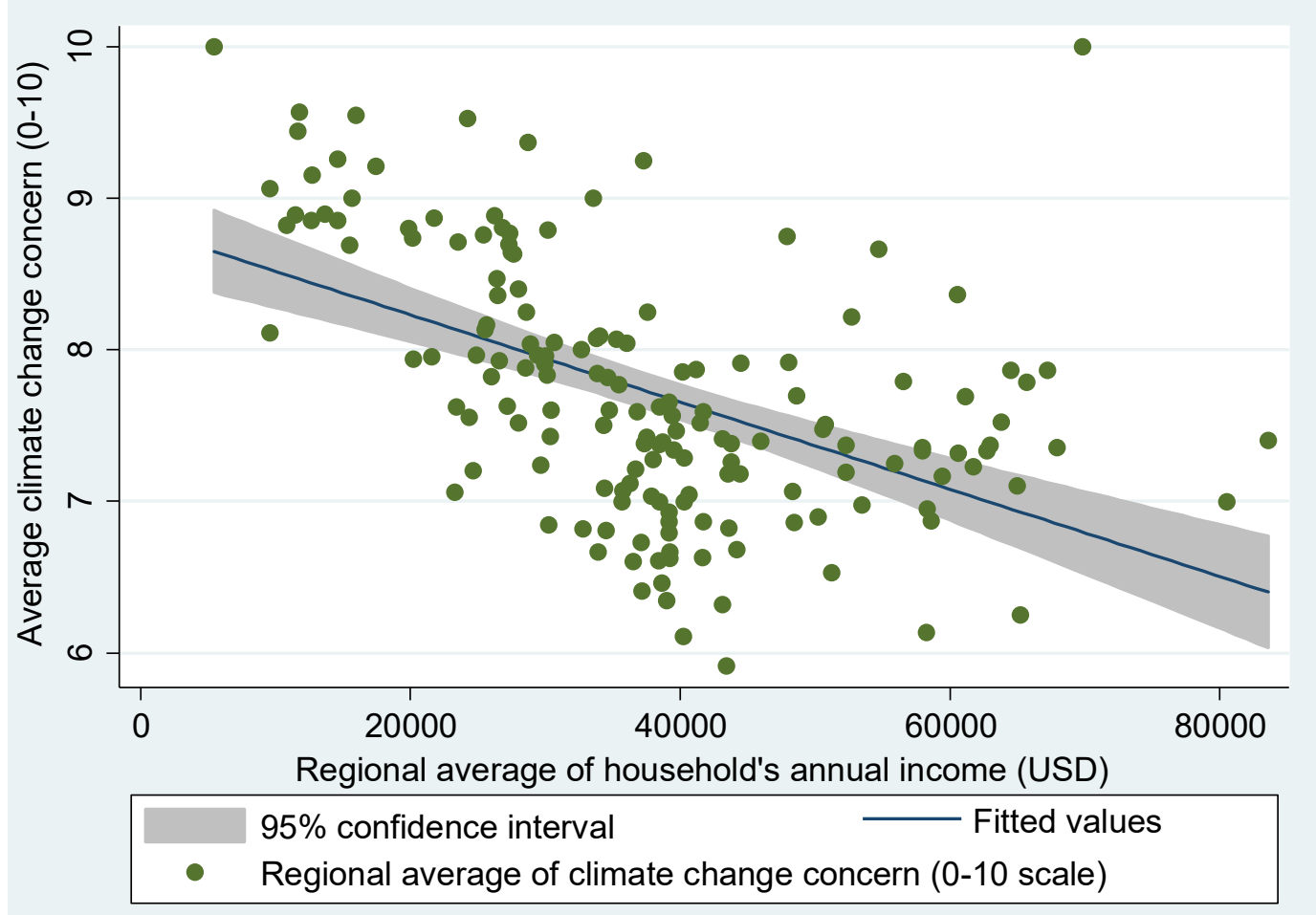

331 Figure 5 illustrates that higher average regional adoption of costly actions (energy efficiencyimproving equipment) is negatively related to average regional climate change concern. 


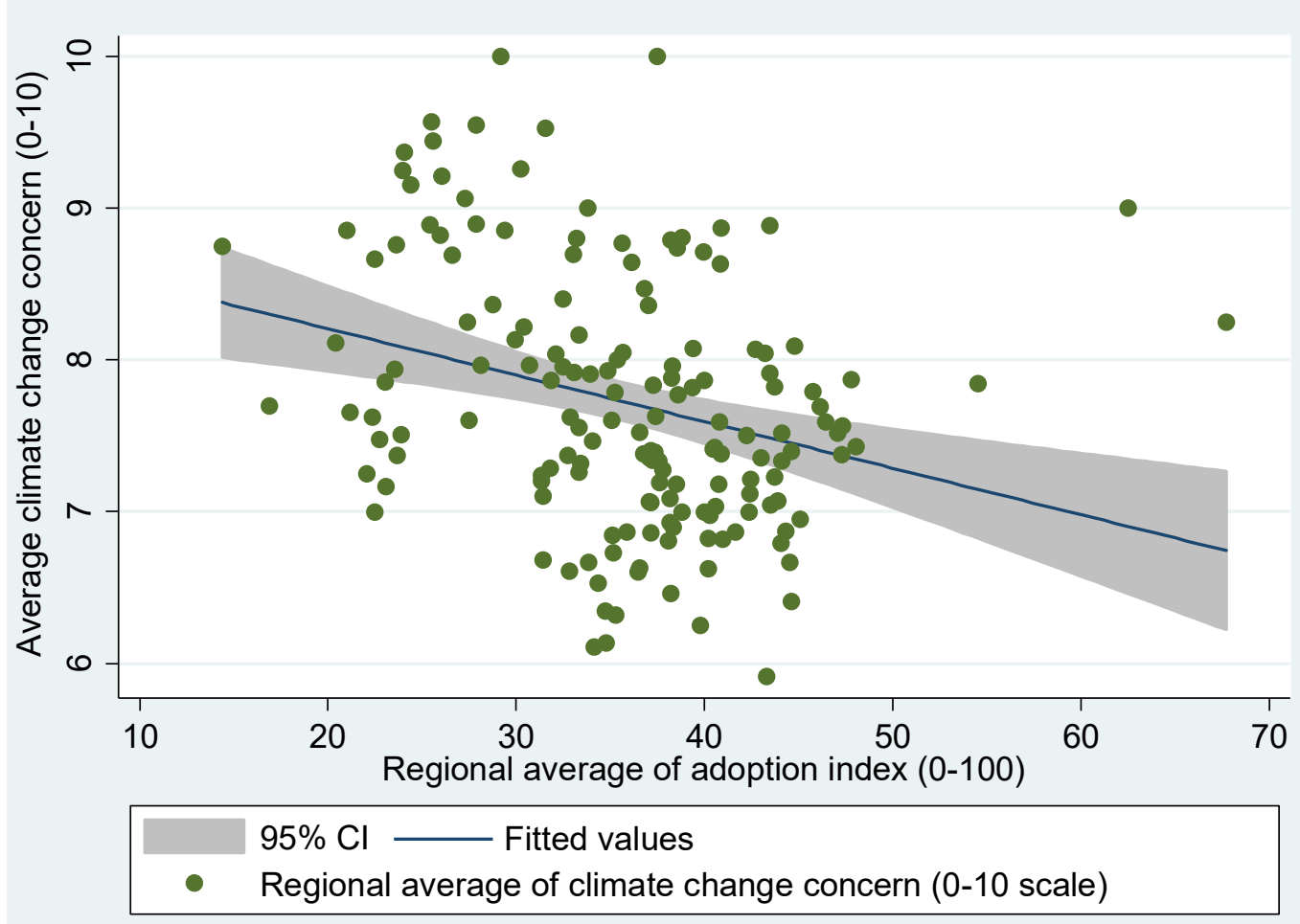

333

Figure 5: Adoption of costly equipment and climate change concern $(n=162)$

\subsection{Testing the role of the readiness score as a mediator of GNI: regression results}

Model 1 in Table 2 tests the relationship between household and country wealth and climate change concern, including the range of control variables described above. The model is globally significant and the Likelihood Ratio test confirms the better performance of the mixed multi-level model featuring both fixed and random effects over the traditional linear regression model (assuming fixed effects only). Results confirm hypothesis H1, that is, the negative relationship between wealth and climate change concern, both at the household and country levels. The estimated coefficients of household's income and GNI per capita are both negative and highly statistically significant, hence the negative relationship between wealth and climate change concern still holds while controlling for a set of other known influences on climate change beliefs. 
Table 2. Multi-level linear models of respondents' climate change beliefs combining fixed and random parameters $(n=10,162$ household-level observations)

\begin{tabular}{|c|c|c|c|c|c|c|}
\hline & \multicolumn{3}{|c|}{ Model 1 (no mediation) } & \multicolumn{3}{|c|}{ Model 2 (with mediation) } \\
\hline & Coef. & $\begin{array}{l}\text { Std. } \\
\text { Err. }\end{array}$ & $P>t$ & Coef. & $\begin{array}{l}\text { Std. } \\
\text { Err. }\end{array}$ & $P>t$ \\
\hline \multicolumn{7}{|l|}{ Respondents' characteristics } \\
\hline Male & $-0.48 * * *$ & 0.038 & 0 & $-0.481 * * *$ & 0.038 & 0 \\
\hline Age & 0.001 & 0.001 & 0.686 & 0.001 & 0.001 & 0.631 \\
\hline Higher education & -0.049 & 0.048 & 0.31 & -0.047 & 0.048 & 0.325 \\
\hline Personal safety ranking & $0.177 * * *$ & 0.013 & 0 & $0.176 * * *$ & 0.013 & 0 \\
\hline Trust experts & $0.353 * * *$ & 0.048 & 0 & $0.354 * * *$ & 0.048 & 0 \\
\hline Charity giving & 0.058 & 0.057 & 0.316 & 0.055 & 0.059 & 0.349 \\
\hline $\begin{array}{l}\text { Local environment } \\
\text { satisfaction }\end{array}$ & $-0.065 * * *$ & 0.016 & 0 & $-0.065 * * *$ & 0.016 & 0 \\
\hline Conservative ideology & $-0.295 * * *$ & 0.067 & 0 & $-0.293 * * *$ & 0.066 & 0 \\
\hline \multicolumn{7}{|l|}{ Households' characteristics } \\
\hline Children & $0.082 * *$ & 0.04 & 0.043 & $0.079^{*}$ & 0.04 & 0.051 \\
\hline Income & $-0.004 * * *$ & 0.001 & 0 & $-0.004 * * *$ & 0.001 & 0 \\
\hline Urban location & 0.077 & 0.077 & 0.314 & 0.076 & 0.074 & 0.302 \\
\hline Energy use monitored & $0.142 *$ & 0.074 & 0.054 & $0.144 * *$ & 0.074 & 0.05 \\
\hline \multicolumn{7}{|l|}{ Country characteristics } \\
\hline Gross national income & $-0.07 * * *$ & 0.016 & 0 & 0.014 & 0.022 & 0.528 \\
\hline Overall readiness score & - & - & - & $-21.12 * * *$ & 4.7 & 0 \\
\hline $\begin{array}{l}\text { Environmental performance } \\
\text { index }\end{array}$ & -0.059 & 0.049 & 0.226 & $-0.308 * * *$ & 0.067 & 0 \\
\hline Extreme climate $\%$ & -0.097 & 0.277 & 0.726 & $1.649 * * *$ & 0.433 & 0 \\
\hline Floods & $1.682 * * *$ & 0.275 & 0 & $2.165 * * *$ & 0.216 & 0 \\
\hline $\begin{array}{l}\text { Mean temperature (5 years } \\
\text { previous) }\end{array}$ & $-0.152 * * *$ & 0.036 & 0 & $-0.335 * * *$ & 0.048 & 0 \\
\hline $\begin{array}{l}\text { Mean temperature ratio ( } 100 \\
\text { years previous) }\end{array}$ & $8.117 * * *$ & 1.499 & 0 & $16.322 * * *$ & 2.072 & 0 \\
\hline Right party ruling & $-0.883 * *$ & 0.431 & 0.04 & $-0.861 * * *$ & 0.298 & 0.004 \\
\hline Constant & 1.209 & 3.667 & 0.742 & $23.145 * * *$ & 5.682 & 0 \\
\hline \multirow[t]{2}{*}{ LR test vs. linear model } & chi2(6): & 230.13 & & chi2(6): & 219.11 & \\
\hline & $\begin{array}{l}\text { Prob }> \\
\text { chi2: }\end{array}$ & 0 & & $\begin{array}{l}\text { Prob }> \\
\text { chi2: }\end{array}$ & 0 & \\
\hline Log-likelihood & -20969.9 & & & -20961.76 & & \\
\hline Wald chi2(19): & 755.06 & & & 1026.09 & & \\
\hline Prob > chi2: & 0 & & & 0 & & \\
\hline
\end{tabular}

Notes: Underlined variables have random parameters. ${ }^{*} p<.05,{ }^{* *} p<.01,{ }^{*} * * p<.001$. 
Many of the findings relating to respondents' characteristics are consistent with previous research: higher concern for climate change was reported by females, respondents with higher trust in experts, and those who consider their local environmental quality as poor (Hmielowski et al. 2014; Millock and Nauges 2014; van der Linden 2017; Hornsey et al. 2016) (Table 2). Our results for 11 OECD countries also align with findings of a strong influence of political affiliation on climate change attitudes in developed countries (e.g. Hornsey et al. 2016; Nawrotzki 2012) in that respondents with attitudes aligned with those of conservative parties are less concerned about climate change. An unexpected finding is that respondents who are less concerned by personal safety ranking express higher climate change concern. In relation to household characteristics, respondents who have higher numbers of children in their household and those that have their energy metered (highlighting the importance of economic incentives in the sense that prices paid are directly related to use and hence drive climate change attitudes) express higher concern about climate change.

Regarding country-specific variables, we find that weather events impact the level of climate change concern: respondents living in countries where there is a higher frequency of floods feel more concerned, a finding that is consistent with some past research linking individual experiences of flooding and climate change concern (Spence et al. 2011). Also, once we control for country average temperature, overall increase in temperature over the last five years compared to historical average (over past 100 years) is related to higher climate change concern (cf. van der Linden 2017). Finally, similar to individuals' political leanings, the more a country was governed by conservative ideology at the time of the survey, the less individuals were concerned about climate change.

Estimation results of Model 2 (test of mediation) in Table 2 show that the first requirement of mediation is verified: the coefficient of GNI per capita loses significance while the coefficient of the readiness score is negative and highly significant $(p<0.01)$. The 
parameters of the respondents' and households' characteristics are almost the same as those reported in Model 1. However we observe some slight changes in the parameters of some of the country-specific variables. In particular the coefficient of the variable measuring the average percentage of the population that was affected by natural disasters classified as either droughts, floods, or extreme temperature events in 2009 (extreme climate \%) now becomes highly significant. This variable relates positively to climate change concern, which is what one would expect. This finding is likely to be explained by the fact that country-specific variables are collinear. Our results thus confirm our hypothesis $\mathrm{H} 2$ in that the readiness score, which measures the capacity of the country to cope and adapt with changes in future conditions, mediates the effect of country's wealth on climate change concern.

\subsection{Testing the role of the adoption index as a mediator of households' income:} regression results

We test in this sub-section the role of the adoption of energy-efficient equipment as a mediator of the relationship between household income and climate change concern using data at the regional and country level.

Models 3 and 4 were estimated using 162 observations combining regional averages and country-specific variables (Table 3). Model 3 includes (regional averages) of households' income and country's GNI per capita as measures of wealth. We include the index measuring the adoption of energy-efficient equipment in Model 4 to test for the role of the adoption index as a potential mediator of households' wealth. 


\begin{tabular}{|c|c|c|c|c|c|c|}
\hline & \multicolumn{3}{|c|}{ Model 3 (no mediation) } & \multicolumn{3}{|c|}{ Model 4 (with mediation) } \\
\hline & Coef. & $\begin{array}{l}\text { Std. } \\
\text { Err. }\end{array}$ & $P>t$ & Coef. & $\begin{array}{l}\text { Std. } \\
\text { Err. }\end{array}$ & $P>t$ \\
\hline \multicolumn{7}{|c|}{ Respondents' characteristics (regional average) } \\
\hline Male & 0.046 & 0.291 & 0.874 & 0.320 & 0.297 & 0.284 \\
\hline Age & -0.014 & 0.010 & 0.194 & -0.003 & 0.011 & 0.752 \\
\hline Higher education & -0.348 & 0.322 & 0.282 & -0.004 & 0.362 & 0.991 \\
\hline Personal safety ranking & 0.154 & 0.095 & 0.107 & $0.196 * *$ & 0.097 & 0.046 \\
\hline Trust experts & $0.560 * * *$ & 0.085 & 0.000 & $0.513 * * *$ & 0.095 & 0.000 \\
\hline Charity giving & $1.146^{* * *}$ & 0.358 & 0.002 & $0.809 * *$ & 0.370 & 0.030 \\
\hline $\begin{array}{l}\text { Local environment } \\
\text { satisfaction }\end{array}$ & -0.150 & 0.107 & 0.162 & -0.124 & 0.106 & 0.245 \\
\hline Conservative ideology & -0.262 & 0.490 & 0.593 & 0.225 & 0.505 & 0.656 \\
\hline \multicolumn{7}{|c|}{ Households' characteristics (regional average) } \\
\hline Children & 0.034 & 0.324 & 0.917 & 0.076 & 0.321 & 0.813 \\
\hline Income & $-0.009 * *$ & 0.004 & 0.030 & -0.006 & 0.004 & 0.136 \\
\hline $\begin{array}{l}\text { Adopt energy-efficient } \\
\text { equipment }\end{array}$ & 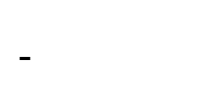 & - & - & $-0.013 * *$ & 0.006 & 0.028 \\
\hline Urban location & $-0.469 * *$ & 0.190 & 0.015 & $-0.528 * * *$ & 0.188 & 0.006 \\
\hline Energy use monitored & 0.039 & 0.495 & 0.938 & 0.101 & 0.483 & 0.834 \\
\hline \multicolumn{7}{|l|}{ Country characteristics } \\
\hline Gross national income & -0.007 & 0.008 & 0.390 & 0.012 & 0.012 & 0.335 \\
\hline Overall readiness score & - & - & - & $-7.843 * *$ & 3.329 & 0.020 \\
\hline $\begin{array}{l}\text { Environmental } \\
\text { performance index }\end{array}$ & $-0.081 * * *$ & 0.019 & 0.000 & $-0.141 * * *$ & 0.036 & 0.000 \\
\hline Extreme climate $\%$ & $0.349 * * *$ & 0.111 & 0.002 & $1.033 * * *$ & 0.295 & 0.001 \\
\hline Floods & $0.700 * * *$ & 0.091 & 0.000 & $0.941 * * *$ & 0.121 & 0.000 \\
\hline $\begin{array}{l}\text { Mean temperature ( } 5 \text { years } \\
\text { previous) }\end{array}$ & $-0.088 * * *$ & 0.013 & 0.000 & $-0.159 * * *$ & 0.031 & 0.000 \\
\hline $\begin{array}{l}\text { Mean temperature ratio } \\
\text { (100 years previous) }\end{array}$ & $3.380 * * *$ & 0.532 & 0.000 & $6.551 * * *$ & 1.390 & 0.000 \\
\hline Right party ruling & $-0.552 * * *$ & 0.160 & 0.001 & -0.177 & 0.200 & 0.380 \\
\hline Constant & $6.331 * * *$ & 1.728 & 0.000 & $11.805 * * *$ & 3.364 & 0.001 \\
\hline R-squared & 0.79 & & & 0.80 & & \\
\hline Fisher-test: & 27.58 & & & 26.76 & & \\
\hline Prob>F: & 0.000 & & & 0.000 & & \\
\hline
\end{tabular}

Table 3. Multiple linear regression models of regional climate change concerns $(n=162$ regional-level observations)
401

402

403

404 
the smaller sample size from using regional averages rather than household-level data. The coefficient of households' income is negative and significant in Model 3 while it loses significance (but remains close to $10 \%$ significance) in Model 4 when the index measuring adoption of energy-efficient equipment is introduced. The index for energy-efficient adoption has a negative and statistically significant coefficient, confirming hypothesis $\mathrm{H} 2$ in that the adoption of energy-efficient equipment mediates the effect of households' income on their climate change concern. $^{7}$

\section{Discussion and conclusions}

In the current study we tested the relationship between wealth and climate change concernat both the household and country level — and explored whether sense of control might mediate this relationship. Our findings confirmed the hypothesized negative relationship between wealth and climate change concern: higher GNI per capita and higher household income (aggregated at the regional level) were both significantly related to lower climate change concern. Consistent with Hypothesis 2, we also found that the negative relationship between GNI and climate change concern became non-significant when sense of control (readiness index) was included in the regression. Similarly, the negative relationship between household level income and climate change concern became non-significant when sense of control (energy-efficiency improving index) was included in the regression.

The mediation results support the proposition that wealth can act as a buffer against risks and reduce climate change concern through increasing a sense of control. Countries that have greater wealth are in a better position to respond to the negative consequences of climate change which in turns provides citizens with collective protection against climate change

\footnotetext{
${ }^{7}$ The country-level mediation (through the readiness score) is less convincing when regional-level rather than when household-level data is used. That is, GNI per capita is not a statistically significant negative predictor in the models that use regional-level household data (i.e. Models 3 and 4). The readiness score is negative and statistically significant in Model 4, similar to the findings of Model 2.
} 
impacts. Household wealth could also provide this buffering effect, allowing householders to ensure against climate change risks and to take action to recover if need be. Wealth, at the country and household level, could therefore afford individuals with a greater sense of control over climate change risks. Although our findings provide support for this proposition, it must be acknowledged that we did not have direct measures of sense of control at the country or household level. Instead, we used an index of a country's ability to adapt through harnessing economic, governance and social resources and an index of the extent to which households had already made their homes energy efficient. We believe these are good proxies for a sense of control, but future research is needed to confirm this and to test the mediation model with direct measures of perceived control. In addition, this study only used OECD nations in their sample, and given that these nations are all relatively privileged, further research should study the climate change concerns of a greater number and diversity of countries around the world.

Previous research has shown conflicting findings for the relationship between wealth and environmental concern with some research showing a positive relationship (Franzen and Vogl 2013a; 2013b; Lo and Chow 2015) whereas other research revealing a negative relationship (Kvaloy et al 2012; Lo 2014; Lo and Chow 2015; Milfont et al 2014; Mostafa 2016; Sandvik 2008). Our findings are consistent with those studies that have found a negative relationship. Consistent with the reasoning of Lo and Chow (2015), we believe that this is because our measure of climate change concern-perceived seriousness of climate change-reflects the risk component of climate change concern rather than the importance component. Other studies showing a negative relationship have also measured the seriousness of climate change (Kvaløy, Finseraas and Listhaug 2012; Mostafa 2016; Sandvik 2008) or climate change/environmental risk perceptions (Lo 2016; Lo and Chow 2015). Hence, our findings provide evidence that the relationship between wealth and climate change concern 
depends on how concern is conceptualized and measured and that, when concern is measured in terms of risk, the relationship with wealth is negative.

The finding that wealth — at the country and household level—is associated with a greater sense of control and less concern for climate change has implications for anyone seeking to promote climate change action. Living in a wealthy country or being part of a wealthy household may lead individuals to feel complacent about the consequences of climate change because they believe that they or their country have the resources to cope with the negative impacts. Previous research has shown that motivation to take action on climate change is related to higher risk perceptions (Hornsey and Fielding 2016; O'Connor, Bord and Fisher 1999; Spence et al. 2011). Hence, the implications of the wealth - climate change concern relationship may be lower levels of support for climate change policy and less individual motivation to engage in climate change mitigation actions. This conclusion highlights an important communication challenge for future researchers, that is, how to promote action on climate change amongst those with the greatest capacity, yet the least motivation to act.

\section{References}

Baron RM, Kenny DA (1986) The moderator-mediator variable distinction in social psychological research: conceptual, strategic, and statistical considerations. Journal of Personality and Social Psychology 51:1173-1182

Beck T, Clarke G, Groff A, Keefer P, Walsh P (2001) New tools in comparative political economy: the database of political institutions. World Bank Economic Review 15(1):165-176

Dunlap RE, Mertig AG (1995) Global concern for the environment: Is affluence a prerequisite? Journal of Social Issues 51(4): 121-137

Dunlap RE, York R (2008) The globalization of environmental concern and the limits of the postmaterialist values explanation: Evidence from four multinational surveys. The Sociological Quarterly 49(3):529-563

Environics Institute (2014) Focus Canada 2014: Canadian public opinion about climate change. Toronto, Canada: Environics Institute. 
European Commission (2017) Special Eurobarometer 459 Report. Brussels, Belgium: European Commission, Directorate-General for Climate Action.

Franzen A, Vogl D (2013a) Two decades of measuring environmental attitudes: a comparative analysis of 33 countries. Global Environmental Change 23(5):1001-1008

Franzen A, Vogl D (2013b) Acquiescence and the willingness to pay for environmental protection: a comparison of the ISSP, WVS, and EVS. Social Science Quarterly 94:637-659

Gassert F, Reig P, Luo T, Maddocks A (2013) Aqueduct country and river basin rankings: a weighted aggregation of spatially distinct hydrological indicators. Working Paper. Washington, DC: World Resources Institute, December.

Available online: http://wri.org/publication/aqueduct-country-river-basin-rankings.

Hmielowski JD, Feldman L, Myers TA, Leiserowitz A, Maibach E (2014) An attack on science? Media use, trust in scientists, and perceptions of global warming. Public Understanding of Science 23:866-883

Hornsey MJ, Fielding KS (2016) A cautionary note about messages of hope: focusing on progress in reducing carbon emissions weakens mitigation motivation. Global Environmental Change 39:26-34

Hornsey MJ, Harris E, Bain PG, Fielding KS (2016) Meta-analyses of the determinants and outcomes of belief in climate change. Nature Climate Change 6:622-626

Inglehart R (1977) The silent revolution: changing values and political styles among western publics. Princeton University Press, Princeton, NJ

Inglehart R (1990) Culture shift in advanced industrial society. Princeton University Press, Princeton, NJ

Kelly PM, Adger, WN (2000) Theory and practice in assessing vulnerability to climate change and facilitating adaptation. Climatic Change, 47, 325-352

Kim S, Wolinsky-Nahmias Y (2014) Cross-national public opinion on climate change: the effects of affluence and vulnerability. Global Environmental Politics 14(1):79-106

Knez I (2013) How concerned, afraid and hopeful are we? Effects of egoism, and altruism on climate change related issues. Psychology 4(10):744-752

Kvaløy B, Finseraas H, Listhaug O (2012) The publics' concern for global warming: a crossnational study of 47 countries. Journal of Peace Research 49:11-22

Lee TM, Markowitz EM, Howe PD, Ko C, and Leiserowitz AA (2015) Predictors of public climate change awareness and risk perception around the world. Nature Climate Change 5:1014-1020

Leiserowitz A, Maibach E, Roser-Renouf C, Rosenthal S, Cutler M, and Kotcher J (2017) Climate change in the American mind: October 2017. Yale University and George Mason University. New Haven, CT: Yale Program on Climate Change Communication.

Lo AY (2016) National income and environmental concern: observations from 35 countries. Public Understanding of Science 25:873-890 
Lo AY and Chow A (2015) The relationship between climate change concern and national wealth. Climatic Change 131:335-348

Lowy Institute (2019) The Lowy Institute Poll 2019: Australian attitudes to climate change. Sydney, Australia: Lowy Institute for International Policy

MacKinnon DP, Fairchild AJ and Fritz MS (2007) Mediation analysis. Annual Review of Psychology 58:593. doi:10.1146/annurev.psych.58.110405.085542

Milfont TL, Evans L, Sibley CG, Ries J, Cunningham A (2014) Proximity to coast is linked to climate change belief. PLoS ONE 9(7): e103180.

https://doi.org/10.1371/journal.pone.0103180

Millock K, Nauges C (2014) Household behaviour and food consumption. In OECD, Greening household behaviour: overview from the 2011 survey - Revised edition (pp. 183217). OECD Studies on Environmental Policy and Household Behaviour, OECD Publishing

Mostafa MM (2016) Post-materialism, religiosity, political orientation, locus of control and concern for global warming: A multilevel analysis across 40 nations. Social Indicators Research 129: 1273-1298.

Nauges C, Wheeler SA (2017) The complex relationship between households' climate change concerns and their water and energy mitigation behaviour. Ecological Economics 141:87-94

Nawrotzki RJ (2012) The politics of environmental concern: a cross-national analysis. Organization \& Environment 25(3):286-307

O’Connor RE, Bord RJ, Fisher A (1999) Risk perceptions, general environmental beliefs, and willingness to address climate change. Risk Analysis 19(3): 461-471

OECD (2014) Greening household behaviour: overview from the 2011 Survey. OECD Publishing, Paris

Ohler A, Billger S (2014) Does environmental concern change the tragedy of the commons?

Factors affecting energy saving behaviors and electricity usage. Ecological Economics 107:112

Ripple WJ, Wolf C, Newsome TM, Galetti M, Alamgir M, Crist E, Mahmoud MI, Laurance WF, 15,364 scientist signatories from 184 countries (2017) World scientists' warning to humanity: a second notice. Bioscience 67(12):1026-1028

Sandvik H (2008) Public concern over global warming correlates negatively with national wealth. Climatic Change 90:333-341

Slovic P (1987) Perception of Risk. Science 236:280-285

Slovic P (2000) The Perception of Risk. Earthscan

Spence A, Poortinga W, Butler C, Pidgeon NF (2011) Perceptions of climate change and willingness to save energy related to flood experience. Nature Climate Change 1:46-49

Stern PC (2000) Toward a coherent theory of environmentally significant behavior. Journal of Social Issues 56:407-424 
555 van der Linden S (2017) Determinants and measurement of climate change risk perception,

556 worry, and concern. In M. Nisbet (Ed.), Oxford Research Encyclopedia of Climate Science.

557 Oxford, UK: Oxford University Press. 
Table A1. Definition and sources of the variables used in the regression models

\begin{tabular}{|c|c|}
\hline \multicolumn{2}{|c|}{ Respondent-specific variables (all sourced from OECD survey) } \\
\hline $\begin{array}{l}\text { Climate change concern } \\
\text { (dependent variable) }\end{array}$ & $\begin{array}{l}\text { respondent's ranking of climate change seriousness on a scale } \\
\text { from } 0 \text { (not at all serious) to } 10 \text { (extremely serious) }\end{array}$ \\
\hline Male & $\begin{array}{l}\text { respondent's gender: takes the value } 1 \text { if the respondent is a } \\
\text { male, and } 0 \text { otherwise }\end{array}$ \\
\hline Age & respondent's age measured in number of years \\
\hline Higher education & $\begin{array}{l}\text { respondent's education: takes the value } 1 \text { if the respondent } \\
\text { completed one or more years of education after high school, } 0 \\
\text { otherwise }\end{array}$ \\
\hline Personal safety ranking & $\begin{array}{l}\text { respondent's ranking of the seriousness of personal safety } \\
\text { issues among a list of six issues in total (international } \\
\text { tensions, economic concerns, environmental concerns, health } \\
\text { concerns, social issues, and personal safety). These six issues } \\
\text { were ranked from } 1 \text { (most important) to } 6 \text { (least important). } \\
\text { The variable b2_rank_safety corresponds to the ranking } \\
\text { attributed by the respondent }\end{array}$ \\
\hline Trust experts & $\begin{array}{l}\text { respondent's opinion on trustworthiness with regard to } \\
\text { information on claims about the environmental impact of } \\
\text { products, coming from researchers, scientists, and experts, on } \\
\text { scale from } 0 \text { (not at all trustworthy) to } 10 \text { (very trustworthy) }\end{array}$ \\
\hline Charity giving & $\begin{array}{l}\text { takes the value } 1 \text { if the respondent has supported or } \\
\text { participated in the activities of charitable organisations } \\
\text { (includes membership, personal time, and/or financial } \\
\text { donations), } 0 \text { otherwise }\end{array}$ \\
\hline $\begin{array}{l}\text { Local environment } \\
\text { satisfaction }\end{array}$ & $\begin{array}{l}\text { respondent's average level of satisfaction towards air quality, } \\
\text { water quality (in lakes, rivers, sea), access to green spaces, } \\
\text { level of noise, and management of litter and rubbish in his/her } \\
\text { local environment. For each of these five items the } \\
\text { respondent indicated satisfaction on a five-degree scale: }-2 \\
\text { (very dissatisfied) to } 2 \text { (very satisfied). The index is the } \\
\text { average of the five scores }\end{array}$ \\
\hline Conservative ideology & $\begin{array}{l}\text { takes the value } 1 \text { if the respondent agreed or strongly agreed } \\
\text { with the following two statements: "Environmental issues } \\
\text { should be dealt with primarily by future generations" and } \\
\text { "Environmental issues will be resolved primarily through } \\
\text { technological progress", } 0 \text { otherwise }\end{array}$ \\
\hline \multicolumn{2}{|c|}{ Household-specific variables (all sourced from OECD survey) } \\
\hline Children & $\begin{array}{l}\text { takes the value } 1 \text { if there is at least one household member } \\
\text { who is below } 18 \text { years of age, } 0 \text { otherwise }\end{array}$ \\
\hline Income & household annual after tax income in thousand USD \\
\hline Urban location & $\begin{array}{l}\text { takes the value } 1 \text { if the household lives in a major town/city } \\
\text { or in a suburban area, } 0 \text { otherwise }\end{array}$ \\
\hline Energy use monitored & $\begin{array}{l}\text { takes the value } 1 \text { if the household pays for electricity } \\
\text { according to how much electricity is used, } 0 \text { otherwise }\end{array}$ \\
\hline
\end{tabular}




\begin{tabular}{|c|c|}
\hline $\begin{array}{l}\text { Adopt energy-efficient } \\
\text { equipment }\end{array}$ & $\begin{array}{l}\text { index measuring adoption of energy-efficient equipment over } \\
\text { the last } 10 \text { years }(0-100 \text { scale })\end{array}$ \\
\hline \multicolumn{2}{|c|}{ Country-specific variables (various sources) } \\
\hline Gross national income & $\begin{array}{l}\text { per capita Gross National Income in 2011, in thousand USD } \\
\text { (World Bank) }\end{array}$ \\
\hline Overall readiness score & $\begin{array}{l}\text { The Environmental Performance Index ( } 0 \text { - } 100 \text { scale) ranks } \\
\text { how well countries perform on high-priority environmental } \\
\text { issues in two broad policy areas: protection of human health } \\
\text { (e.g., child mortality, air pollution, access to drinking water } \\
\text { and sanitation) and protection of ecosystems (e.g., wastewater } \\
\text { treatment, pesticide regulation, changes in forest cover, fish } \\
\text { stocks, carbon intensity trends). A higher index indicates a } \\
\text { better protection (http://epi.yale.edu/) }\end{array}$ \\
\hline $\begin{array}{l}\text { Environmental } \\
\text { performance index }\end{array}$ & $\begin{array}{l}\text { "Readiness measures a country's ability to leverage } \\
\text { investments and convert them to adaptation actions. ND- } \\
\text { GAIN (Notre Dame - Global Action Initiative) measures } \\
\text { overall readiness by considering three components - } \\
\text { economic readiness, governance readiness and social } \\
\text { readiness" (ND-GAIN } \\
\text { (http://index.gain.org/about/methodology) }\end{array}$ \\
\hline Extreme climate $\%$ & $\begin{array}{l}\text { Average percentage of the population that was affected by } \\
\text { natural disasters classified as either droughts, floods, or } \\
\text { extreme temperature events in } 2009 \text { (World Bank }{ }^{9} \text { ) }\end{array}$ \\
\hline Floods & $\begin{array}{l}\text { Number of floods recorded from 1985-2011 (Gassert et al. } \\
\text { 2013; World Resources Institute) }\end{array}$ \\
\hline $\begin{array}{l}\text { Mean temperature ( } 5 \text { years } \\
\text { previous) }\end{array}$ & $\begin{array}{l}\text { Mean temperature over the years 2006-2010 (source: } \\
\text { https://www.ncdc.noaa.gov/data-access) }\end{array}$ \\
\hline $\begin{array}{l}\text { Mean temperature ratio } \\
\text { (100 years previous) }\end{array}$ & $\begin{array}{l}\text { Ratio of mean temperature over } 2006-2010 \text { to mean } \\
\text { temperature over } 1911-2010\end{array}$ \\
\hline Right party & $\begin{array}{l}\text { Takes the value } 1 \text { if the main orientation of the political party } \\
\text { ruling the government in } 2011 \text { is classified as "right" } \\
\text { including parties that are defined as conservative/Christian } \\
\text { democratic/right-wing; (World Bank Database of Political } \\
\text { Institutions; Beck et al. 2001) }\end{array}$ \\
\hline
\end{tabular}

\footnotetext{
${ }^{8}$ Additional notes from ND-GAIN: "Economic readiness captures the ability of a country's business environment to accept investment that could be applied to adaptation that reduces vulnerability (reduces sensitivity and improves adaptive capacity). Governance readiness captures the institutional factors that enhance application of investment for adaptation. Social readiness captures the factors such as social inequality, Information and Communication Technology infrastructure, education, and innovation that enhance the mobility of investment and promote adaptation actions."

${ }^{9}$ Additional notes from the World Bank: "A drought is an extended period of time characterized by a deficiency in a region's water supply that is the result of constantly below average precipitation. Extreme temperature events are either cold waves or heat waves. Population affected is the number of people injured, left homeless or requiring immediate assistance during a period of emergency resulting from a natural disaster; it can also include displaced or evacuated people.” Source: http://data.worldbank.org/indicator/EN.CLC.MDAT.ZS
} 


\begin{tabular}{|c|c|c|c|c|}
\hline Variable & Mean & Std. Dev. & Min & Max \\
\hline \multicolumn{5}{|c|}{ Respondent-specific variables } \\
\hline Climate change concern & 7.64 & 2.20 & 0 & 10 \\
\hline Male & 0.51 & 0.50 & 0 & 1 \\
\hline Age & 42.19 & 13.63 & 18 & 69 \\
\hline Higher education & 0.79 & 0.41 & 0 & 1 \\
\hline Personal safety ranking & 4.24 & 1.56 & 1 & 6 \\
\hline Trust experts & 7.03 & 1.92 & 0 & 10 \\
\hline Charity giving & 0.28 & 0.45 & 0 & 1 \\
\hline $\begin{array}{l}\text { Local environment } \\
\text { satisfaction }\end{array}$ & -0.13 & 1.19 & -2.0 & 1.8 \\
\hline Conservative ideology & 0.10 & 0.30 & 0 & 1 \\
\hline \multicolumn{5}{|c|}{ Household-specific variables } \\
\hline Children & 0.39 & 0.49 & 0 & 1 \\
\hline Income (USD) & 49,133 & 32,029 & 2,985 & 206,145 \\
\hline Urban location & 0.66 & 0.47 & 0 & 1 \\
\hline Energy use monitored & 0.92 & 0.27 & 0 & 1 \\
\hline $\begin{array}{l}\text { Adopt energy-efficient } \\
\text { equipment }\end{array}$ & 35.54 & 27.11 & 0 & 100 \\
\hline \multicolumn{5}{|l|}{ Country-specific variables } \\
\hline $\begin{array}{l}\text { Gross national income } \\
\text { Overall readiness }\end{array}$ & 42,771 & 17,280 & 12,290 & 79,320 \\
\hline $\begin{array}{l}\text { score } \\
\text { Environmental }\end{array}$ & 74.41 & 6.98 & 63.55 & 88.17 \\
\hline performance index & 0.75 & 0.07 & 0.64 & 0.86 \\
\hline Extreme climate \% & 0.36 & 0.85 & 0.00 & 3.05 \\
\hline Floods & 2.52 & 0.79 & 0.35 & 3.47 \\
\hline $\begin{array}{l}\text { Mean temperature ( } 5 \\
\text { years previous) }\end{array}$ & 10.47 & 7.05 & -4.40 & 21.74 \\
\hline $\begin{array}{l}\text { Mean temperature ratio } \\
\text { (100 years previous) }\end{array}$ & 1.08 & 0.13 & 0.81 & 1.38 \\
\hline Right party & 0.56 & 0.50 & 0 & 1 \\
\hline
\end{tabular}

